\title{
Efficacy of Reduced-Risk Insecticides to Control Flower Thrips in Early-Season Blueberries and Their Effect on Orius insidiosus, a Natural Enemy of Flower Thrips
}

\author{
Oscar E. Liburd, Hector Alejandro Arevalo, Elena M. Rhodes \\ Entomology and Nematology Department, University of Florida, Gainesville, FL, USA \\ Email: oeliburd@ufl.edu
}

How to cite this paper: Liburd, O.E., Arevalo, H.A. and Rhodes, E.M. (2017) Efficacy of Reduced-Risk Insecticides to Control Flower Thrips in Early-Season Blueberries and Their Effect on Orius insidiosus, a Natural Enemy of Flower Thrips. Agricultural Sciences, 8, 356-370.

https://doi.org/10.4236/as.2017.85027

Received: March 17, 2017

Accepted: May 16, 2017

Published: May 22, 2017

Copyright $\odot 2017$ by authors and Scientific Research Publishing Inc. This work is licensed under the Creative Commons Attribution International License (CC BY 4.0).

http://creativecommons.org/licenses/by/4.0/

\begin{abstract}
Flower thrips are one of the key pests in production of southern highbush blueberries (Vaccinium corymbosum L. $\times V$. darrowi Camp). They feed on the reproductive parts of the flower and reduce yield. Very few insecticides are available to manage thrips population. Therefore, it is necessary to evaluate pre-existing and experimental insecticides for their efficacy against thrips. There is also a high demand for reduced-risk insecticides that are less toxic to beneficial insects and the environment. In this study, a number of conventional and reduced-risk insecticides were evaluated against flower thrips on farms in Florida and Georgia and in the laboratory. The best performing insecticides were also evaluated in the laboratory for their effects on Orius insidiosus Say, which is a common thrips' predator in Florida. Assail 70WP (Acetamiprid) and SpinTor 2SC (Spinosad) were the most promising insecticides in reducing thrips numbers in the field as well as in laboratory experiments. SpinTor 2SC killed all of the thrips in laboratory arenas within 4 hours of application and showed low toxicity toward $O$. insidiosus. All of the compounds tested performed as well as the conventional pesticide malathion.
\end{abstract}

\section{Keywords}

Blueberries; Flower Thrips, Frankliniella, Insecticides, Orius insidiosus

\section{Introduction}

Flower thrips are among the most damaging insect pests in the production of southern highbush blueberries (Vaccinium corymbosum L. $\times$ V. darrowi Camp) 
[1] [2] [3] [4] [5]. The use of chemical means to control thrips began in the early 1900s. Since then, no insecticide has been developed to target exclusively thysanopteran pests. All of the insecticides used for thrips management were designed to control other insects and then tested on thrips. However, their effect on thrips might be limited due to differences in behavior and feeding habits compared with other major pests [6]. Insecticides recommended for thrips control by the manufacturers are usually systemic and stomach poisons. There are a few insect-growth regulators and contact-only insecticides, but these are very limited [6].

The United States congress [7], warned of the use of traditional chemistries and encouraged the development of new chemistries that are less toxic to non-target organisms and to the environment in general. There are a number of reduced-risk chemistries biopesticides, and organophosphates $(\mathrm{OP})$ alternatives that are labeled or in process of being labeled to be used in blueberries. Within this group, only five have shown potential to control thrips: flonicamid, novaluron, spinosad, thiamethoxam, and zeta-cypermethrin [7] [8]. Novaluron is an insect growth regulator that targets immature insects and interfering with their normal development. Alternatively, thiamethoxam belongs to the class of insecticides called neonicotinoids, which kill insects by mimicking acetylcholine at the synapse preventing the receptors from distinguishing between acetylcholine and nicotine.

Prior to 2008 most of the chemical control for flower thrips in blueberries has relied on the use of malathion, an organophosphate (OP) insecticide, and on SpinTor 2SC (Spinosad), a reduced-risk naturalyte product (insecticide) from the bacterium Saccharopolyspora spinosa. Malathion has been used to control flower thrips in various crops including garlic, leek, onion, cucumbers, endive, etc. [9]. Spinosad is being used as an organic OMRI-listed insecticide in its formulation Entrust, or as non-organic formulation as SpinTor 2SC. Spinosad is labeled to control thrips in bushberries, citrus, Brassica vegetables, cucurbits, etc. [10] [11]. However, concerns for the development of insect resistance due to the use of few chemistries and a limited number of modes of action, prevails.

Several studies have reported various degrees of thrips resistance to several insecticides. Jensen [12] compiled a list of Frankliniella occidentalis (Pergande) wild and laboratory populations that have been reported as resistant to insecticides. The list includes seven OP's, nine carbamates, eight pyrethroids and six other chemistries, which include endosulfan, DDT, and the OP-alternative imidacloprid. In a study in Australia, Herron and James [13] reported resistance of F. occidentalis to chlorpyrifos, dichlorvos, and malathion. At the same time resistant individuals where detected for acephate, dimethoate, endosulfan, fipronil, mathemidophos, methidathion, and spinosad. Laboratory selections using fipronil and spinosad were successful in rearing increasingly resistant populations of thrips and this was the first report of induced resistance of Frankliniella thrips to spinosad and fipronil.

Another consideration when using chemical alternatives to control thrips in 
integrated pest management (IPM) is the effect of these insecticides on nontarget organisms, principally natural enemies. The effect of traditional and reduced-risk insecticides to non-target organisms is well documented. To mention a few examples, studies on natural enemies of thrips include Geocoris punctipes [14] [15] [16] [17], Orius spp. [15] [18] [19], and Amblyseius spp. [20]. All these studies demonstrated the lethal and sub-lethal effects of these chemical products on natural enemies. Selective insecticides will conserve natural enemies and facilitate adequate biological control. Insecticides that have little effect on non-target organisms are desirable due to their compatibility with natural enemies, which is the basis for a successful IPM program. The present study shows the relationship between selected reduced-risk insecticides that have the potential to control flower thrips in early-season blueberries and to replace traditional insecticides in commercial fields. The results from the field were complemented with laboratory bioassays to determine the effect of these insecticides under controlled conditions on flower thrips and on Orius insidiosus Say, one of the most common and effective natural enemies for thrips control in Florida [21].

\section{Material and Methods}

\subsection{Field Trials}

Field experiments were conducted from 2004 to 2006 in four commercial blueberry farms located in Florida and southern Georgia. Three farms in Florida (IFL04 located at $\mathrm{N} 28^{\circ} 04^{\prime} \mathrm{W} 81^{\circ} 35^{\prime}$, IFL05 located at $27^{\circ} 30^{\prime} \mathrm{N}, 81^{\circ} 31^{\prime} \mathrm{W}$, and IFL06 $29^{\circ} 40^{\prime} \mathrm{N}, 82^{\circ} 11^{\prime} \mathrm{W}$ ) and one farm located in Georgia (IGA04 located at $31^{\circ} 31^{\prime} \mathrm{N}, 82^{\circ} 27^{\prime} \mathrm{W}$ ) were selected for these trials. Each year the insecticides that showed the most potential from the previous season and a few more insecticides were compared. A selection of reduced-risk insecticides, conventional (traditional) insecticides, and OP alternatives was selected to determine their efficacy. Treatments were sprayed after sunset because of the potential effect of these insecticides on populations of honeybees, Apis mellifera L. as used for blueberry pollination. The plot size varied depending on the farm conditions and the areas where we were allowed to work during each one of the seasons. No insecticides were used on the farm during experimentation, except when treatment application was made. Only one application of the insecticides was used for all treatments at the manufacturer's labelled rates.

The experimental design in all cases was a completely randomized extended block design and each one of the blocks had four replicates of each of treatment evaluated. To determine the effect of insecticides on thrips populations, we deployed a white sticky trap, size $22.8 \times 14.2 \mathrm{~cm}$ (Great Lakes IPM Vestaburg, Michigan) in the middle of each treatment plot and randomly collected 5 flowerclusters from the blueberry bushes holding the traps. White sticky traps are one of the methods used to sample thrips because it has been shown to be very effective in monitoring thrips population and it is easier to identify the thrips to species on a white background compared with other colored traps [5]. Sticky traps 
were deployed in the field one week prior to the application of the treatments. These traps were collected before the application and replaced by a new one, which was located in the same position and collected one week after the treatment.

\subsubsection{IFL04}

This farm located in south central Florida was used for the trials conducted in 2004. Treatments were sprayed two-times during flowering of blueberry bushes with a 14 day interval between sprays as recommended by the Small Fruit and Vegetable IPM Laboratory at the University of Florida (O.E Liburd Personal communication). Insecticide treatments were applied at the doses recommended by the manufacturer. Treatments were sprayed using four-gallon backpack sprayers (Lowe's North Wilkesboro, NC). The sprayers were manually pumped to a maximum capacity and the handle was pumped once every five seconds to maintain a homogeneous pressure. A completely randomized extended block design with eight treatments, four replicates and two blocks were used to evaluate insecticides. The treatments used were: Malathion $5 \mathrm{EC}$ at $139.8 \mathrm{~g}$ a.i./ha, Calypso $480 \mathrm{C}$ (Thiacloprid) at $116.92 \mathrm{~g}$ a.i./ha (Bayer Crop Science Research Triangle North Carolina USA), Assail 70WP (Acetamiprid) at $112.78 \mathrm{~g}$ a.i./ha (du Pont de Nemours and Company, Fayetteville, North Carolina, USA), Novaluron $174.08 \mathrm{~g}$ a.i./ha (Valent BioSciences Cooperation Osage Iowa, USA), SpinTor 2SC (Spinosad) $105 \mathrm{~g}$ a.i./ha (Dow AgroSciences, Indianapolis, Indiana, USA), Knack (Pyriproxyfen) (Valent BioSciences Cooperation Osage Iowa, USA) at $120 \mathrm{~g}$ a.i./ha, GF968 (Spinosad experimental insecticide) at $52.63 \mathrm{~g}$ a.i./ha, and an untreated control. Each plot measured $84 \mathrm{~m}^{2}$ with a $15 \mathrm{~m}$ buffer zone between plots. The selected plot was covered with black bird netting to reduce the attack of birds during harvest.

\subsubsection{IGA04}

This farm located in southern Georgia was planted in rabbiteye blueberries and the trial was conducted during the 2004 flowering season. Selected plots for this trial covered $193 \mathrm{~m}^{2}$ with $12 \mathrm{~m}$ buffer zones between the plots. There were eight treatments and four replicates of each treatment using the same experimental design as above. Insecticides treatments were applied to plots using a 400 gal., tractor-mounted orchard airblast sprayer. Treatments evaluated included Malathion $5 \mathrm{EC}$ at $139.8 \mathrm{~g}$ a.i./ha, Calypso 480C (Thiacloprid) at $116.92 \mathrm{~g}$ a.i./ha, Assail 70WP (Acetamiprid) at $112.78 \mathrm{~g}$ a.i./ha, Pedestal (Novaluron) $174.08 \mathrm{~g}$ a.i./ha, SpinTor 2SC (Spinosad) $105 \mathrm{~g}$ a.i./ha, Knack (Pyriproxyfen) at $120 \mathrm{~g}$ a.i./ha, Actara 25WG (Thiamethoxam) $78.80 \mathrm{~g} / \mathrm{ha}$, and an untreated control.

\subsubsection{IFL05}

Located in south Florida, this farm used low density southern highbush blueberries. Treatments were sprayed during the 2005 flowering season using an airblast sprayer as described above at the manufacturer recommended doses. The treat- 
ments included were Malathion $5 \mathrm{EC}$ at $139.8 \mathrm{~g}$ a.i./ha, SpinTor 2SC (Spinosad) $105 \mathrm{~g}$ a.i./ha, Assail 30SG (Acetamiprid) (used as TD 2480 acetamiprid-experimental insecticide) $5.4 \mathrm{oz} /$ acre, Assail 70WP (Acetamiprid) $112.77 \mathrm{~g} / \mathrm{ha}$, Diamond 0.83EC (Novaluron) $145.35 \mathrm{~g} / \mathrm{ha}$, Actara 25WP (Thiamethoxam) 78.80 $\mathrm{g} / \mathrm{ha}$. Treatments were applied in plots of $471 \mathrm{~m}^{2}$ with $9 \mathrm{~m}$ of buffer zone between treatments and $41 \mathrm{~m}$ between blocks of 7 treatments. Each treatment had four replicates.

\subsubsection{IFL06}

This farm was located in north-central Florida and was planted with southern highbush blueberries. Treatments were sprayed during the 2006 flowering season using a $\mathrm{CO}_{2}$ sprayer calibrated at $23 \mathrm{PSI}$ and using a Teejet hollow cone spray core D3 disk DC 25 (Spraying systems Co. Keystone Heights, FL). There were four replicates per treatment and the plots were distributed in a completely randomized extended block design. Each plot covered $219.46 \mathrm{~m}^{2}$ and buffers between treatments were $30.4 \mathrm{~m}$ long with $4 \mathrm{~m}$ between rows. The treatments used in this farm were: Malathion $5 \mathrm{EC}$ at $139.8 \mathrm{~g}$ a.i./ha, SpinTor 2SC (Spinosad) $105 \mathrm{~g}$ a.i./ha, Diamond 0.83EC (Novaluron) $145.35 \mathrm{~g} / \mathrm{ha}$, Assail $30 \mathrm{SG}$ (Acetamiprid) $113.48 \mathrm{~g} / \mathrm{ha}$, Actara $25 \mathrm{WG}$ (Thiamethoxam) $78.80 \mathrm{~g} / \mathrm{ha}$, Coragen 20SC (Rynaxpyr) $98.63 \mathrm{~g} / \mathrm{ha}$, and an untreated control.

\subsubsection{Statistical Analyses}

Due to the highly aggregated pattern shown by flower thrips in early-season blueberry fields [22], we analyzed the data by determining the effect of these insecticides using the growth rate $(r)$, which represents the change in thrips population due to the insecticide application. The " $r$ " growth rate or also known as the intrinsic rate of increase is defined as the rate at which a population increase (or decrease) assuming non-density-dependent factors [22].

$$
r=\frac{d N}{d t} \frac{1}{N}
$$

where $r$ growth rate, $N=$ Population size, $\mathrm{t}=$ a determined amount of time.

An $r$ value of 1 represents no change in the population after the application of the treatment. An $r$ value $>1$ indicates that more thrips were captured during the week after the application than the week prior to the application. An $r$ value $<1$ represents a fall in the number of thrips in the week after the application compared with the week before the application.

In the case of sticky traps, we used the total number of thrips captured during the week immediately after treatment divided by the total number of thrips captured at the same location the week prior to the treatment. To analyze the number thrips inside the blueberry flowers, we used the 'shake and rinse' method [23] and divided the number of thrips extracted from five flower-clusters one week after the treatment by the number of thrips extracted from the same amount of flower-clusters collected the day of the treatment in the same blueberry bush. Comparisons were conducted using a one-way ANOVA and LSD 
tests for mean comparison [24].

\subsection{Laboratory Trials}

During the laboratory trials, the eight most promising treatments studied in the field were evaluated. Laboratory trials were divided into two parts 1) toxicity of insecticides to flower thrips and 2) the effect of the insecticides on non-target organisms. With regard to non-target organisms, $O$. insidiosus was selected because it is one of the principal natural enemies of flower thrips in North America [3] [21] [25] [26].

Both organisms were tested in similar arenas, a $300 \mathrm{ml}$ white polyethylene jar (B \& A Products, Ltd. Co., Bunch, Oklahoma). The lids of these jars were modified in such a way that only the rim remained. The jars were covered with non-thrips mesh (Bioquip. Rancho Dominguez, CA) and the modified lids were screwed on over the mesh to prevent the insects from escaping. This modification allowed ventilation of the arenas. For both insects, two green beans were used as the substrate for each treatment. The green beans were cleaned using a solution of $0.6 \%$ sodium hypochlorite and de-ionized (DI) water for ten minutes, then rinsed with DI water and allowed to air dry for $2 \mathrm{~h}$. Green beans were sprayed with insecticide solutions using a hand-held spray atomizer that released $2 \mathrm{ml}$ of solution per spray (two sprays per treatment). The green beans were then air-dried for two hours and then placed inside the arenas.

Orius insidiosus was initially obtained from Koppert Biological Systems (Romolus, MI) and raised in a laboratory colony that was started approximately 2 months prior to the start of the experiments. The colony was maintained on Ephestia kuehniella Zeller eggs purchased from Koppert Biological Systems, The Netherlands. Orius insidiosus was reared in a Percival Environmental Chamber (Percival Scientific Inc., Perry Iwoa) set at $26^{\circ} \mathrm{C} \pm 2^{\circ} \mathrm{C}, 70 \% \pm 10 \% \mathrm{RH}$ and a 14-hour photo-phase.

At the start of the assay, $10 \mathrm{O}$. insidiosus were released into an arena. The number of live $O$. insidiosus was recorded at selected times after the release. During this trial, 5 live adult thrips (from laboratory colony) not previously exposed to insecticides were added to each one of the replicates every two hours. Thrips that were found dead inside the $O$. insidiosus arenas were removed. The thrips addition was done with the objective of feeding the predators as if they were under field conditions. Treatments were prepared at the same concentrations as in field experiments assuming 935 liters/ha (100 U.S gallons/acre) unless otherwise specified on the label. The treatments selected for $O$. insidiosus were Actara $25 \mathrm{WG}$ (Thiamethoxam) at $78.80 \mathrm{~g}$ a.i./ha, Assail 70WP (Acetamiprid) at $112.77 \mathrm{~g}$ a.i./ha, Malathion 5EC (Malathion) $139.8 \mathrm{~g}$ a.i/ha, and SpinTor 2SC (Spinosad) at $105 \mathrm{~g}$ a.i./ha. These insecticides were either the most commonly used or they had the highest potential to control thrips in blueberry fields as observed in the field experiments. This experiment was designed as a completely randomized experiment with six replicates.

Data were analyzed hour by hour using a one-way ANOVA table and the 
treatments were compared using LSD mean separation tests $(\alpha=0.05)$.

Flower thrips were collected in blueberry fields in north-central Florida and brought to the laboratory for identification. Frankliniella bispinosa (Morgan) was selected because it was the most abundant thrips recorded in Florida according to our field survey. Thrips were kept under laboratory conditions $\left(27^{\circ} \mathrm{C}\right.$ and $70 \% \mathrm{RH}$ ) for two days before the trials began. The colonies were fed with a mixture of honey and pollen spread over green beans, which were cleaned using a $0.6 \%$ sodium hypochlorite and de-ionized (DI) water as described above. Active-adult thrips were selected for the trials and divided into groups of ten. These were randomly released into the arenas once the treated green beans were dry and in place. Experiments were organized in completely randomized designs with five replicates. Treatments tested on the thrips included Assail 70WP at $112.7 \mathrm{~g}$ a.i./ha, Calypso $480 \mathrm{C}$ at $116.9 \mathrm{~g}$ a.i./ha, Knack at $120 \mathrm{~g}$ a.i./ha, GF 968 (an spinosad experimental) at $52.63 \mathrm{~g}$ a.i./ha, Malathion at 5EC $139.8 \mathrm{~g}$ a.i./ha, Novaluron, SpinTor 2SC at $105 \mathrm{~g}$ a.i./ha and an untreated control.

Analysis was conducted using ANOVA which compared the mortality rates according to treatments and mean separation was done using LSD ( $\alpha=0.05)$ [24].

The experiments lasted until no more mortality was observed in the treatments, for thrips the laboratory experiment lasted $12 \mathrm{~h}$ and for $O$. insidiosus lasted $24 \mathrm{~h}$. Preliminary experiments with $O$. insidiosus had indicated that the insecticides had a delayed effect on these predatory insects. During the preliminary experiments conducted under the same conditions, most of the deaths occurred between 10 and $20 \mathrm{~h}$ after exposure to the treated green beans. For this reason, most of the observations were taken during this interval.

\section{Results}

\subsection{Field Trials}

\subsubsection{IFL04}

When observing the effectiveness of the insecticide on thrips populations located inside the flowers in this farm, only two insecticides had a significantly lower $r$ values than the control: Novaluron $(r=1.1 \pm 0.8)$ and Assail 70WP $(r=0.55 \pm$ $0.08)(F=9.24$, df $=7,53 ; P<0.0001)$. Novaluron's $r$ value was significantly lower than Malathion 5EC, Knack, and GF968, but it was significantly higher than Assail 70WP (Acetamiprid), which was the only compound that reduced thrips population inside blueberry flowers as shown by $r<1$ (Figure 1). In the floating thrips populations, those collected in the sticky traps, similar results were observed. Assail 70WP had the lowest $r$ value and was significantly lower than all the other treatments including the control. The growth rate $(r)$ for Novaluron and Malathion was significantly lower than SpinTor 2SC but not significantly different from any of the other treatments with exception of Assail, $(F=$ 5.22, $\mathrm{df}=7,53 ; P<0.0001)$. SpinTor $2 \mathrm{SC}$ had the highest $r$ value in the sticky traps (Figure 2). 


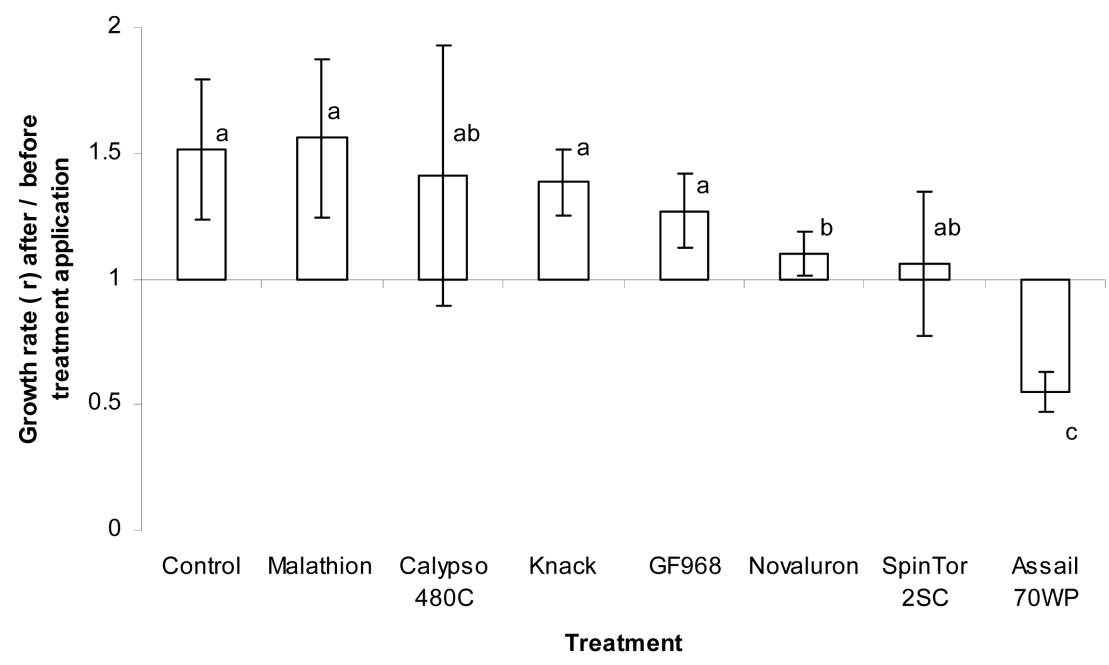

Figure 1. Average growth rate $(r)$ between the week before treatment application and the week after the application of the treatments. Thrips populations correspond to the thrips recovered from the flowers collected in IFL04. Significant differences with control are marked by $\left[{ }^{*}\right]$ when compared using LSD test $(\alpha=0.05)$.

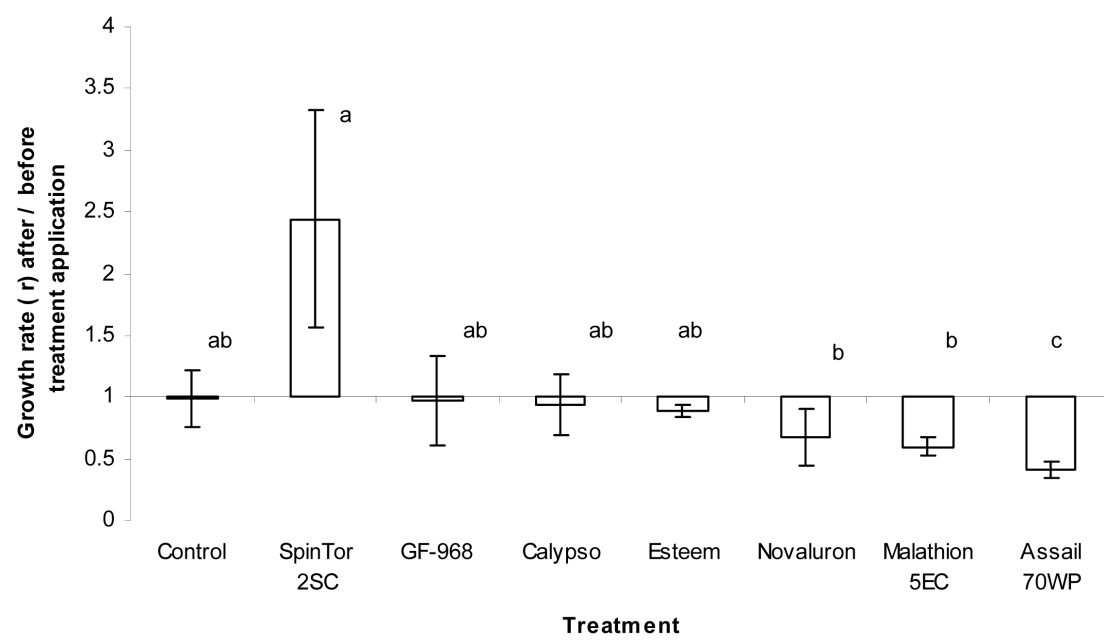

Figure 2. Average growth rate $(r)$ between the week before treatment application and the week after the application of the treatments. Thrips populations correspond to the thrips captured in white sticky traps collected in IFL04. Significant differences with control are marked by $\left[{ }^{*}\right]$ when compared using LSD test $(\alpha=0.05)$.

\subsubsection{IGA04}

The results obtained in Georgia in 2004 did not show significant differences among the treatments $(F=0.66, \mathrm{df}=7,54 ; P=0.7456)$. However, the floating population in all of the treatments decreased during this season in similar proportions (Figure 3), which might indicate that the reduction in thrips population was independent of the insecticide treatments.

\subsubsection{IFL05}

There was very limited activity of thrips during this flowering season on the selected farm. For this reason, it was not possible to collect enough data for a robust analysis to show the effect of these insecticides on thrips populations inside 
the flowers. However, increasing numbers of thrips captured in the white sticky traps was observed. In all the treatments, the populations increased, possibly as a result of immigration since the amount of thrips inside the flowers where they reproduce was very limited. None of treatments was significantly different from the control. However, Actara $25 \mathrm{WG}$ and Assail $70 \mathrm{WP}$ significantly reduced the population growth when compared with Malathion $5 \mathrm{EC},(F=4.79, \mathrm{df}=6,48 ; P$ $=0.0004)$, but they were not significantly different from any of the other treatments including the control (Figure 4).

\subsubsection{IFL06}

On the experiments conducted in Florida in 2006, none of treatments was sig-

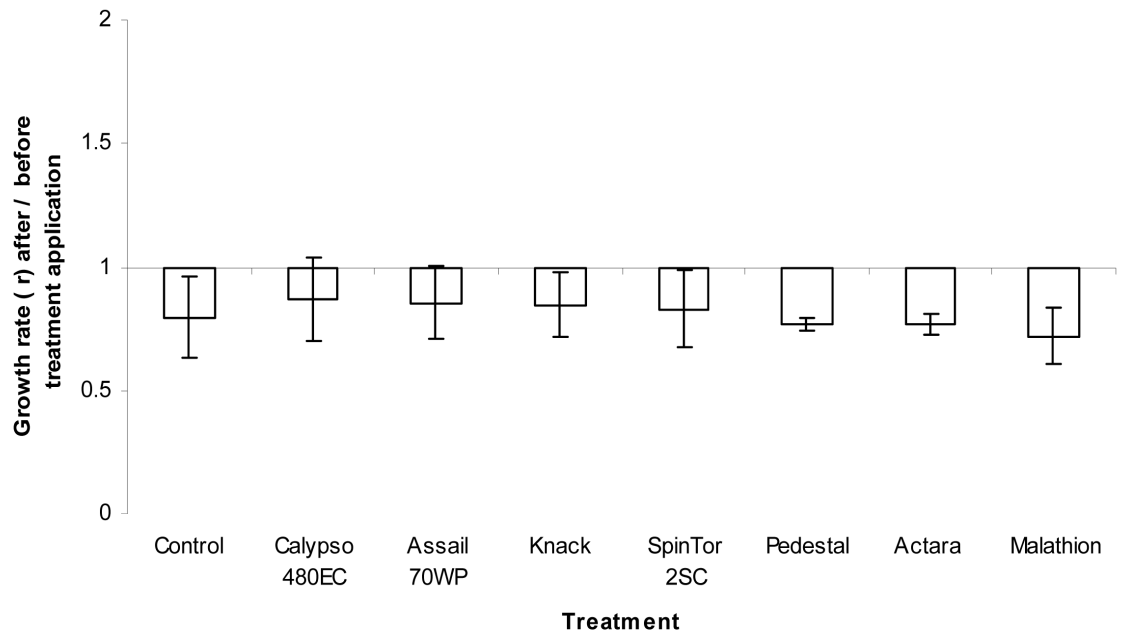

Figure 3. Average growth rate $(r)$ between the week before treatment application and the week after the application of the treatments. Thrips populations correspond to the thrips captured in white sticky traps collected in IGA04.

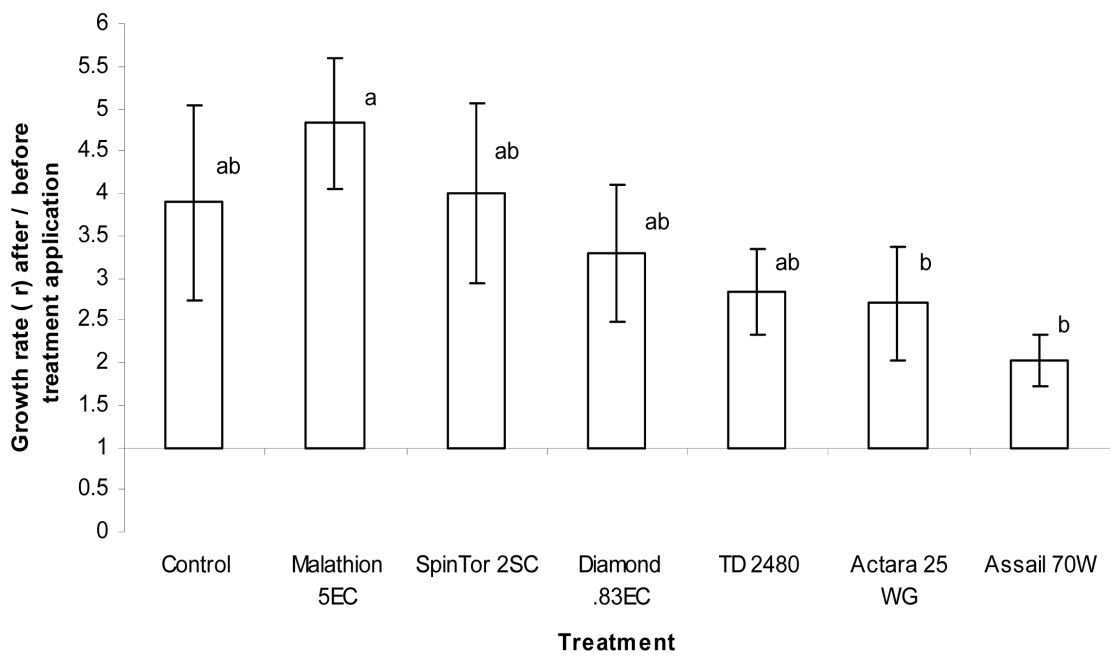

Figure 4. Average growth rate $(r)$ between the week before treatment application and the week after the application of the treatments. Thrips populations correspond to the thrips captured in white sticky traps collected in IFL05. Significant differences are represented by different letters when compared using LSD test $(\alpha=0.05)$. 
nificantly different from the control when comparing the $r$ value for the sticky traps $(F=4.01, \mathrm{df}=6,48 ; P=0.0016)$ or inside the flowers $(F=0.48, \mathrm{df}=6,48$; $P=0.7275)$. The $r$ value for the thrips captured in the sticky traps increased over time independent of treatment applications, with the exception of Coragen 20SC $(r=0.93 \pm 0.21)$, which was the only treatment with $r<1$. Coragen 20SC had a significantly lower $r$ value than Diamond 0.83 . However, the comparisons of all other treatments were non-significant (Figure 5). On the established populations collected from the flowers, the situation was similar to the situation encountered in the sticky traps. None of treatments significantly reduced the population growth $(r)$ when they were compared.

\subsection{Laboratory Trials}

\subsubsection{Thrips Bioassay}

All the insecticides were effective against thrips in the laboratory. From $1 \mathrm{~h}$ after the release of thrips in the arenas, all the treatments had significantly less thrips surviving when compared with the control $(F=13.86$; $\mathrm{df}=8,36 ; P<0.001)$. After $1 \mathrm{~h}$ of contact with the treated green beans, all of the insecticides killed half of the insects exposed to the treatments. Three of the treatments, Actara 25WG, Assail $70 \mathrm{WP}$, and Malathion 5EC, reduced the population to less than one third of the original size within the first hour (Table 1). The only insecticide that killed all the thrips exposed to it was SpinTor 2SC. This insecticide, in less than four hours, reduced the population to zero. However, this result was not significantly different to Assail 70 WP, Knack, and Malathion 5EC. Six hours after the thrips were exposed to the treated green beans; all the treatments were not significantly different from each other except for the control. After $6 \mathrm{~h}$ of exposure to insecticides, all of the insecticides virtually eliminated the thrips in the arena.

\subsubsection{Orius insidiosus Bioassay}

Three of the four treatments tested killed more than $70 \%$ of the $O$. insidiosus

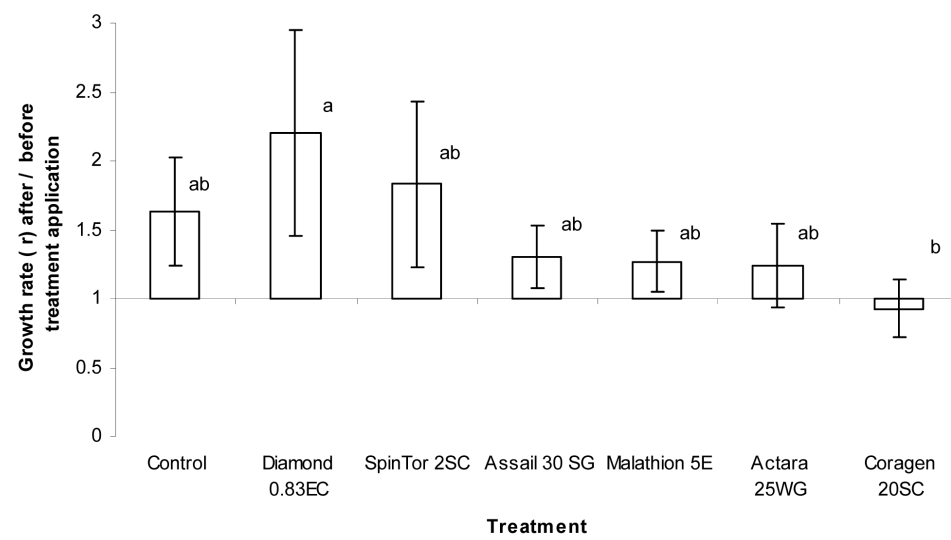

Figure 5. Average growth rate $(r)$ between the week before treatment application and the week after the application of the treatments. Thrips populations correspond to the thrips captured in white sticky traps collected in IFL06. Significant differences are represented by different letters when compared using LSD test $(\alpha=0.05) .1 / \operatorname{sqrt}(\mathrm{x})$ 
Table 1. Proportion of Frankliniella bispinosa surviving at various times after release into the bioassay arenas in 2004 .

\begin{tabular}{ccccc}
\hline \multicolumn{5}{c}{ Hours after the release (HAR) of Frankliniella bispinosa in 2004 } \\
\hline Treatments & 1 & 4 & 6 & 12 \\
\hline Control & $1.00 \pm 0.00(\mathrm{a})$ & $1.00 \pm 0.00(\mathrm{a})$ & $0.92 \pm 0.02(\mathrm{a})$ & $0.92 \pm 0.02(\mathrm{a})$ \\
Actara 25 WG & $0.15 \pm 0.04(\mathrm{e})$ & $0.02 \pm 0.02(\mathrm{~d})$ & $0.02 \pm 0.02(\mathrm{bc})$ & $0.02 \pm 0.02(\mathrm{~b})$ \\
Assail 70 WP & $0.25 \pm 0.02(\mathrm{de})$ & $0.06 \pm 0.03(\mathrm{~cd})$ & $0.02 \pm 0.02(\mathrm{bc})$ & $0.02 \pm 0.02(\mathrm{~b})$ \\
Calypso 480C & $0.39 \pm 0.04(\mathrm{bcd})$ & $0.11 \pm 0.05(\mathrm{bc})$ & $0.06 \pm 0.02(\mathrm{bc})$ & $0.02 \pm 0.02(\mathrm{~b})$ \\
Knack & $0.38 \pm 0.05(\mathrm{bcd})$ & $0.04 \pm 0.02(\mathrm{~cd})$ & $0.04 \pm 0.03(\mathrm{bc})$ & $0.02 \pm 0.02(\mathrm{~b})$ \\
GF 968 & $0.41 \pm 0.04(\mathrm{bc})$ & $0.12 \pm 0.03(\mathrm{bc})$ & $0.03 \pm 0.03(\mathrm{bc})$ & $0.03 \pm 0.03(\mathrm{~b})$ \\
Malathion & $0.29 \pm 0.07(\mathrm{cde})$ & $0.04 \pm 0.02(\mathrm{~cd})$ & $0.02 \pm 0.02(\mathrm{bc})$ & $0.02 \pm 0.02(\mathrm{~b})$ \\
Novaluron & $0.49 \pm 0.07(\mathrm{~b})$ & $0.16 \pm 0.04(\mathrm{~b})$ & $0.07 \pm 0.04(\mathrm{~b})$ & $0.03 \pm 0.03(\mathrm{~b})$ \\
SpinTor 2SC & $0.39 \pm 0.08(\mathrm{bcd})$ & $0.00 \pm 0.00(\mathrm{~d})$ & $0.00 \pm 0.00(\mathrm{c})$ & $0.00 \pm 0.00(\mathrm{~b})$ \\
\hline
\end{tabular}

Means followed by the same letter within each column are not significantly different from each other when compared using LSD test $(\alpha=0.05) .1 \mathrm{HAR}(F=13.86 ; \mathrm{df}=8,36 ; P<0.001) ; 4 \mathrm{HAR}(F=47.08 ; \mathrm{df}=8,36 ; P$ $<0.001) ; 6 \operatorname{HAR}(F=84.56 ; \mathrm{df}=8,36 ; P<0.001) ; 12 \operatorname{HAR}(F=115.00 ; \mathrm{df}=8,36 ; P<0.001)$.

used in the bioassays after $24 \mathrm{~h}$. SpinTor 2SC was the insecticide that killed the lowest proportion of predators (Table 2). The most lethal insecticide was Actara $25 \mathrm{WG}$, which killed almost all the insects in the first $20 \mathrm{~h}$. Throughout the duration of the experiment, Actara $25 \mathrm{WG}$ and Assail $70 \mathrm{WP}$ had, consistently, the lowest survival rate compared with all the other treatments. Neither treatment (Actara 25 WG and Assail $70 \mathrm{WP}$ ) was significantly different from each other. Fast acting treatments, Actara $25 \mathrm{WG}$ and Assail $70 \mathrm{WP}$, started showing significant differences with the control one hour after exposure $(F=4.87 ; \mathrm{df}=4,25 ; P$ $=0.0016)$. Ten hours later only one treatment, SpinTor 2SC, was not significantly different from the control $(F=8.09 ; \mathrm{df}=4,25 ; P<0.001)$. This situation was true for the initial $12 \mathrm{~h}$ after exposure $(F=11.87$; $\mathrm{df}=4,25 ; P<0.001)$. Fifteen hours after exposure SpinTor $2 \mathrm{SC}$ showed significant differences with the control, but was the chemical treatment with the highest proportion of survivors $(0.73 \pm 0.04)$ (Table 2).

\section{Discussion}

In this study, nine commercial insecticides and three experimental insecticides were tested under various locations, methods of application, and cultivars. Among the treatments used, Assail (Acetamiprid) in its two formulations, Assail 70 WP (used in IFL04, IGA04, and IFL05), and Assail 30SG used in IFL05 (as experimental TD 2480) and in IFL06, were the most consistent of the insecticides in controlling the population growth rate $(r)$ of flower thrips in blueberries. Assail is a reduced-risk insecticide labeled for thrips control in cotton, cole crops and fruiting vegetables. As a result of this work and other similar research, Assail received partial registration for thrips in blueberries in 2008 (in selected states in the US). This eventually led to a national label for thrips in blueberries in all 
Table 2. Proportion of Orius insidiosus surviving at various times after release into bioassay arenas.

\begin{tabular}{|c|c|c|c|c|c|c|}
\hline \multirow[b]{2}{*}{ Treatments } & \multicolumn{6}{|c|}{ Hours after the release (HAR) of Orius insidiosus } \\
\hline & 1 & 10 & 12 & 15 & 20 & 24 \\
\hline Control & $1.00 \pm 0.00(\mathrm{a})$ & $1.00 \pm 0.00(\mathrm{a})$ & $0.96 \pm 0.03(\mathrm{a})$ & $0.96 \pm 0.03(a)$ & $0.96 \pm 0.03(a)$ & $0.93 \pm 0.06(a)$ \\
\hline $\begin{array}{c}\text { Actara } 25 \\
\text { WG }\end{array}$ & $0.56 \pm 0.06(b)$ & $0.56 \pm 0.06(\mathrm{c})$ & $0.36 \pm 0.06(c)$ & $0.33 \pm 0.04(\mathrm{c})$ & $0.06 \pm 0.06(d)$ & $0.03 \pm 0.03(\mathrm{~d})$ \\
\hline $\begin{array}{c}\text { Assail } 70 \\
\text { WP }\end{array}$ & $0.63 \pm 0.03(\mathrm{~b})$ & $0.63 \pm 0.03(b c)$ & $0.36 \pm 0.13(c)$ & $0.20 \pm 0.07(\mathrm{c})$ & $0.20 \pm 0.07(\mathrm{~d})$ & $0.20 \pm 0.07(\mathrm{~cd})$ \\
\hline Malathion & $0.87 \pm 0.04(\mathrm{a})$ & $0.80 \pm 0.00(b)$ & $0.73 \pm 0.04(b)$ & $0.66 \pm 0.04(b)$ & $0.50 \pm 0.07(c)$ & $0.30 \pm 0.04(\mathrm{c})$ \\
\hline $\begin{array}{c}\text { SpinTor } \\
2 \text { SC }\end{array}$ & $0.90 \pm 0.04(\mathrm{a})$ & $0.90 \pm 0.04(\mathrm{a})$ & $0.90 \pm 0.04(\mathrm{a})$ & $0.73 \pm 0.04(\mathrm{~b})$ & $0.70 \pm 0.04(b)$ & $0.70 \pm 0.04(\mathrm{~b})$ \\
\hline
\end{tabular}

Means with the same letter within each column are not significantly different from each other when compared using LSD test $(\alpha=0.05)$. for $1 \mathrm{HAR}(F=4.87 ; \mathrm{df}=4,25 ; P=0.0016) ; 10 \mathrm{HAR}(F=8.09, \mathrm{df}=4,25 ; P$ $<0.001) ; 12 \operatorname{HAR}(F=11.87 ; \mathrm{df}=4,25 ; P<0.001) ; 15 \operatorname{HAR}(F=18.24 ; \mathrm{df}=4,20 ; P<0.001) ; 20 \operatorname{HAR}(F=$ $17.42 ; \mathrm{df}=4,20 ; P<0.001) ; 24 \operatorname{HAR}(F=26.31 ; \mathrm{df}=4,20 ; P<0.001)$.

states a few years later. Acetamiprid had been mentioned by Morishita [27] as effective in thrips control under laboratory conditions. In the laboratory bioassays, Assail 70WP was fast acting, reducing the number of thrips to one-forth of the initial population after the first hour of exposure. Assail 70WP (Acetamiprid) belong to the class neonicotinoids, which poison insects by mimicking acetylcholine at the synapse and subsequently preventing the receptors from distinguishing between acetylcholine and nicotine. Subsequently, after $6 \mathrm{~h}$ of exposure the number of surviving thrips was virtually zero (Table 1). Assail 70WP is toxic to $O$. insidiosus during the first ten hours of exposure. After 10 hours, the population declines rapidly from $63 \%$ to $20 \%$ over the next five hours. After 15 h, Assail $70 \mathrm{WP}$ seems to have no effect on the surviving $O$. insidiosus. This is important since this time frame can safely permit inundative releases of $O$. insidiosus in biological control programs for management of thrips in blueberry.

SpinTor 2SC (Spinosad) is another reduced-risk insecticide that has been used for thrips control in several crops including berries, cotton, grapes, and tubers among several others. In the laboratory experiments, SpinTor 2SC was the first insecticide that killed $100 \%$ of the thrips exposed to treated green beans. At the same time SpinTor 2SC was the most compatible treatment with $O$. insidiosus. In the laboratory, $70 \%$ of $O$. insidiosus survived after $24 \mathrm{~h}$ of exposure. Despite that, the treatment had significantly fewer survivors than the control. However, SpinTor 2SC was the insecticide that had the least effect on $O$. insidiosus among the insecticides screened, having significantly more survivors than any of the other treatments (Table 2). The number of survivors was significantly lower than the control after $15 \mathrm{~h}$ of exposure to treated green beans. This 'lag time' has been observed with other species such as Geocoris punctipes Say [17] and in blueberry maggot, Rhagoletis mendax Curran [28].

In the field, SpinTor 2SC did not have a significant effect on thrips populations. In all cases, both populations exposed to SpinTor 2SC, floating and estab- 
lished, increased and were among the populations with the highest $r$ values, with the exception of the established population, collected from flowers, in 2004 at IFL04. However, it was not significantly different from the control or any of treatments used that year with the exception of Assail $70 \mathrm{WP}$, which was significantly lower (Figure 1). The reduced effectiveness in the field might be related to the low residual activity of this insecticide. In field experiments in egg plants, spinosad lost all activity after six days [29]. If the residual activity of Spinosad is similar in blueberries this would indicate that there is not enough residual time to protect the blueberry bushes for the time between applications (two weeks).

Malathion, a conventional insecticide, was not significantly different from the control in any of the observations conducted. In the laboratory bioassays, Malathion was one of the fastest acting products. It killed more than $2 / 3$ of the population in the first hour. Four hours after the treatment, Malathion killed almost all the thrips exposed to the treated green beans (Table 1). In the O. insidiosus bioassay, Malathion killed significantly fewer predators than Actara at all times, but significantly more than SpinTor 2SC. On average Malathion killed close to $70 \%$ of the $O$. insidiosus individuals after $24 \mathrm{~h}$ (Table 2).

The use of growth rate $(r)$ in the field, as the ratio of the population after the treatments divided by the population before the treatments, reduces the risk of misinterpretation of the data in cases where insect populations are not uniform or randomly distributed. In the case of flower thrips in blueberries, the distribution is highly aggregated [22], thus analysis of the final number of thrips captured after the applications might be affected by the presence of a "hot-spot" or aggregation sites in places where samples are taken. The use of $r$ will reduce this problem by taking into consideration the initial populations inside the treatments before the applications. However, it assumes that external conditions, such as temperature, immigration, and rain, affect all the plots within a block similarly. It appears that the population growth of thrips in blueberry fields is associated more with immigration than with the populations found in the fields. Every day more and more thrips arrive to the fields while the insecticides are active for only short periods of time. For this reason, in most of the cases, the population rates after/before the application was more than 1. From these results, any of the reduced-risk insecticides tested in these experiments were equally as or more effective than Malathion to control flower thrips in blueberries. Assail $70 \mathrm{WP}$, and Assail 30 SG (experimental Acetamiprid) was the most effective and consistent of treatments reducing the growth rate $(r)$ of flower thrips in the field. These results were also corroborated by the results in the laboratory. SpinTor 2SC was as effective as any of the other treatments and at the same time the most compatible with $O$. insidiosus which is one of the main natural enemies, so it will be a good alternative in places where natural enemies are a high priority. In recent years, SpinTor $2 \mathrm{SC}$ has been replaced with Spinetoram, a related product, and the formulation Delegate ${ }^{\oplus}$ (Dow AgroSciences, Indianapolis, Indiana, USA) is used in commercial blueberry production for management of thrips. 


\section{References}

[1] Finn, E. (2003) Developing Integrated Pest Management (IPM) Techniques for Managing Key Insect Pests of Blueberries in the Southern United States. MSc Thesis, Entomology and Nematology Department, University of Florida, Gainesville, 11 +99 .

[2] Liburd, O.E. and Finn, E. (2003) Evaluation of Conventional and Reduced-Risk Insecticides for Control of Flower Thrips. Berry Vegetable Times, 3, 3-4.

[3] Liburd, O.E. and Arévalo, H.A. (2005) Integrated Strategies for Controlling Flower Thrips in Southern Highbush Blueberries. University of Florida, IFAS Extension IPM-140, Gainesville.

[4] Liburd, O.E. and Arévalo, H.A. (2006) Insects and Mites in Blueberries. In: Childers, N.F. and Lyrene, P.M., Eds., Blueberries for Growers, Gardeners, Promoters, Dr. Norman F. Childers Horticultural Publications, Gainesville, 99-110.

[5] Liburd, O.E., Sarzynski, E.M., Arévalo, H.A. and MacKenzie, K. (2009) Monitoring and Emergence of Flower Thrips Species in Rabbiteye and Southern Highbush Blueberries. Acta Horticulturae, 810, 251-258. https://doi.org/10.17660/ActaHortic.2009.810.32

[6] Lewis, T. (1997) Chemical Control. In: Lewis, T., Ed., Thrips as Crop Pests, CAB International, Wallingford, 567-594.

[7] United States Congress (104th) (1996) Food Quality Protection Act of 1996. http://www.epa.gov

[8] IR 4 Project (2006) New Pest Control Technologies. Rutgers University, New Brunswick.

[9] Micro Flo Company (2006) Malathion 5EC. In: ChemSearch CDMS, Crop Data Management Systems, Inc. http://www.cdms.net

[10] Dow AgroSciences (2006) Entrust Naruralyte Insect Control (Original Label + Supplemental Labels). In: ChemSearch CDMS, Crop Data Management Systems, Inc.

[11] Dow AgroSciences (2006) Spinosad Naruralyte Insect Control (Original Label + Supplemental Labels). In: ChemSearch CDMS, Crop Data Management Systems, Inc.

[12] Jensen, S.E. (2000) Insecticide Resistance in the Western Flower Thrips, Frankliniella occidentalis. Integrated Pest Manage Review, 5, 131-146.

https://doi.org/10.1023/A:1009600426262

[13] Herron, G.A. and James, T.M. (2005) Monitoring Insecticide Resistance in Australian Frankliniella occidentalis Pergande (Thysanoptera: Thripidae) Detects Fipronil and Spinosad Resistance. Australian Journal of Entomology, 44, 299-303. https://doi.org/10.1111/j.1440-6055.2005.00478.x

[14] Mizell, R.F. and Sconyers, M.C. (1992) Toxixity of Imidacloprid to Selected Arthropod Predators in the Laboratory. Florida Entomologist, 75, 277-280. https://doi.org/10.2307/3495632

[15] Elzen, G.W., Elzen, P.J. and King, E.G. (1998) Laboratory Toxicity of Insecticide Residues to Orius insidiosus, Geocoris punctipes, Hippodamia convergens, and Chrysoperla carnea. Southwest Entomologist, 23, 335-342.

[16] Elzen, G. W. (2001) Lethal and sublethal effects of insecticide residues on Orius insidiosus (hemiptera: Anthocoridae) and Geocoris punctipes (Hemiptera: Lygaeidae). Journal of Economic Entomology, 94, 55-59. https://doi.org/10.1603/0022-0493-94.1.55

[17] Myers, L., Liburd, O.E. and Arévalo, H.A. (2006) Survival of Geocoris punctipes Say 
(Hemiptera: Lygaeidae) Following Exposure to Selected Reduced-Risk Insecticides. Journal of Entomological Science, 41, 57-64.

[18] Ludwig, S. and Oetting, R. (2001) Effect of Spinosad on Orius insidiosus (Hemiptera: Anthocoridae) When Used for Frankliniella occidentalis (Thysanopter: Thripidae) Control on Green Houses. Florida Entomologist, 84, 311-313. https://doi.org/10.2307/3496189

[19] Studebaker, G.E. and Kring, J.B. (2003) Effects of Insecticides on Orius insidiosus (Hemiptera: Anthocoridae), Measured by Field, Greenhouse and Petri Dish Bioassays. Florida Entomologist, 86, 178-184. https://doi.org/10.1653/0015-4040(2003)086[0178:EOIOOI]2.0.CO;2

[20] Castagnoli, M., Angeli, G., Liguori, M., Forti, D. and Simoni, S. (2002) Side Effects of Botanical Insecticides on Predatory Mite Amblyseius andersoni (Chant). Journal of Pest Science, 75, 122-127. https://doi.org/10.1046/j.1472-8206.2002.02035.x

[21] Funderburk, J., Stavisky, J. and Olson, S. (2000) Predation of Frankliniella occidentalis (Thysanoptera: Thripidae) in Field Peppers by Orius insidiosus (Hemiptera: Anthocoridae). Environmental Entomology, 29, 376-382.

https://doi.org/10.1093/ee/29.2.376

[22] Birch, L. (1948) The Intrinsic Rate of Natural Increase of an Insect Population. The Journal of Animal Ecology, 1, 15-26. https://doi.org/10.2307/1605

[23] Arévalo, H.A. and Liburd, O.E. (2007) Horizontal and Vertical Distribution of Flower Thrips in Southern Highbush and Rabbiteye Blueberry Plantings, with Notes on a New Sampling Method for Thrips Inside Blueberry Flowers. Journal of Economic Entomology, 100, 1622-1632. https://doi.org/10.1093/jee/100.5.1622

[24] SAS Institute Inc. (2002) SAS System for Windows Computer Program, Version 9.00. SAS Institute Inc., Cary.

[25] Van de Veire, M. and Degheele, D. (1995) Comparative Laboratory Experiment with Orius insidiosus and Orius albipidipennis (Het: Anthocoridae), Two Candidates for Biological Control in Green Houses. Entomophaga, 40, 341-344. https://doi.org/10.1007/BF02373721

[26] Shipp, J.L. and Wang, K. (2003) Evaluation of Amblyseius cucumeris (Acari: Phytoseiidae) and Orius insidiosus (Hemiptera: Anthocoridae) for Control of Frankliniella occidentalis (Thysanoptera: Thripidae) on Green House Tomatoes. Biological Control, 28, 271-281.

[27] Morishita, M. (2001) Toxicity of Some Insecticides to Larvae of Flankliniella occidentalis (Pergande) (Thysanoptera: Thripidae) Evaluated by the Petri Dish-Spraying Tower Method. Applied Entomology and Zoology, 36, 137-141. https://doi.org/10.1303/aez.2001.137

[28] Liburd, O.E., Finn, E., Pettit, K.L. and Wise, J.C. (2003) Response of Blueberry Maggot fly (Diptera: Tephritidae) to Imidacloprid-Treated Spheres and Selected Classes of Insecticides. Canadian Entomologist, 135, 427-438. https://doi.org/10.4039/n02-080

[29] McLeod, P., Diaz, F.J. and Johnson, D.T. (2002) Toxicity, Persistence, and Efficacy of Spinosad, Chlorfenapyr, and Thiamethoxam on Eggplant When Applied against the Eggplant Flea Beetle (Coleoptera: Chrysomelidae). Journal of Economic Entomology, 95, 331-335. https://doi.org/10.1603/0022-0493-95.2.331 
Submit or recommend next manuscript to SCIRP and we will provide best service for you:

Accepting pre-submission inquiries through Email, Facebook, LinkedIn, Twitter, etc. A wide selection of journals (inclusive of 9 subjects, more than 200 journals)

Providing 24-hour high-quality service

User-friendly online submission system

Fair and swift peer-review system

Efficient typesetting and proofreading procedure

Display of the result of downloads and visits, as well as the number of cited articles Maximum dissemination of your research work

Submit your manuscript at: http://papersubmission.scirp.org/

Or contact as@scirp.org 